Jose Ma. C. Avila, M.D.

Department of Pathology

College of Medicine

University of the Philippines Manila
Correspondence: Jose Ma. C. Avila, M.D. University of the Philippines Manila

College of Medicine

Department of Pathology

547 Pedro Gil St. Ermita, Manila, 1000

Phone (632) 5264550

Fax (632) 4003638

\section{Fine Needle Aspiration Cytology of Schwannoma of the Parotid Gland}

This 52-year-old male underwent fine needle aspiration biopsy of a 2-cm diameter parotid mass that was firm, well-delineated and vaguely moveable,

The mass was not painful and was noted for about a year. The aspiration biopsy smear was quite cellular and showed fragments of spindle-shaped cells with cigar shaped nuclei and scanty to indistinct cytoplasms. Nuclei were vesicular and Verocay-like bodies were identified by cell patterns. The biopsy was read as a benign spindle cell tumor, probably a schwannoma.

Excision of the mass revealed a typical schwannoma by histopathology.

Schwannomas of the parotid gland are rare ${ }^{1}$ and arise from the intraparotid branches of the facial nerve. Clues to the cytologic diagnosis include the cellular but benign spindly cell population clustered into Verocay body patterns and evidence of cyst degeneration in the form of histiocytes and even lymphocytes. ${ }^{2}$ Main differential diagnoses include the predominant spindle cell myoepitheliomas ${ }^{3}$ and some of the low grade sarcomas that may arise from the parotid gland. The even rarer schwannomalike mixed tumor of the parotid ${ }^{4}$ gland must be also considered.

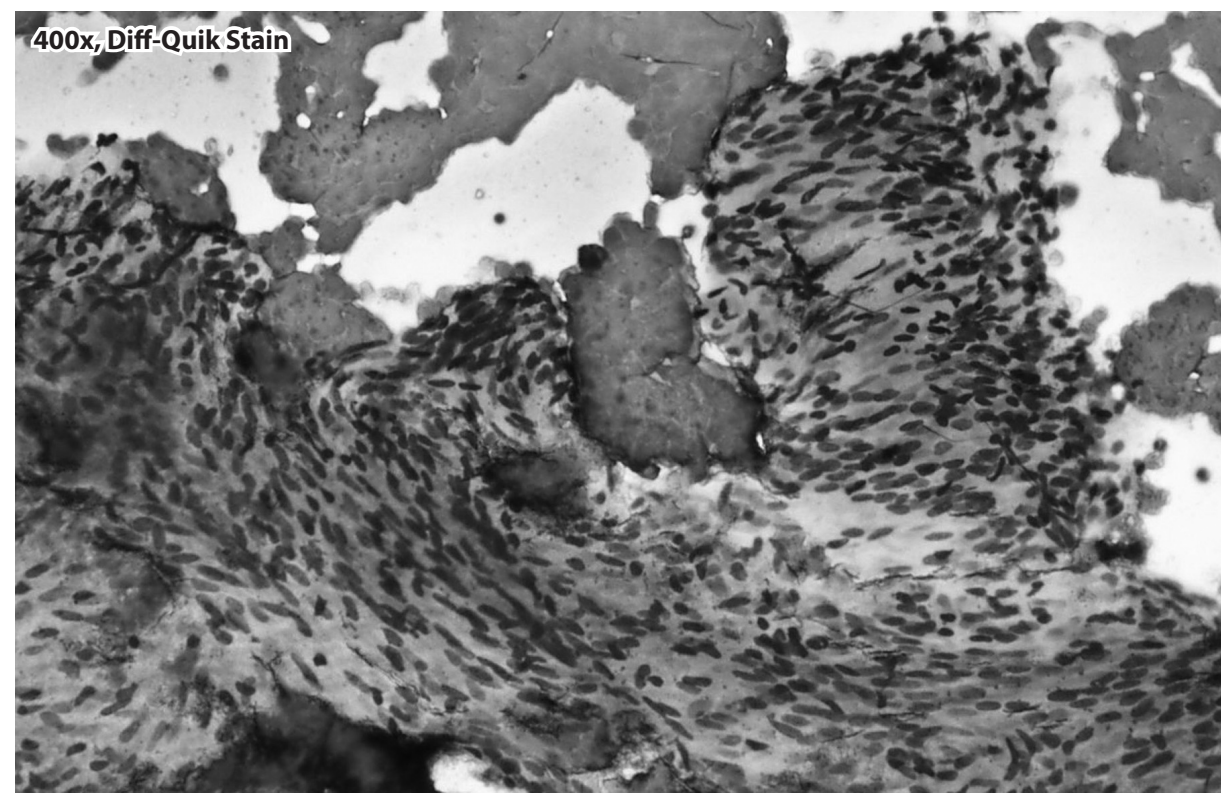

REFERENCES

1. Falconi M, Russo A, Taibah A, Sanna M. Facial nerve tumors. Otol Neurotol. 2003 Nov; 24(6):942-7

2. Maly B, Maly A, Doviner V, Reinhartz T, Sherman Y. Fine needle aspiration biopsy of intraparotid schwannoma-a case report. Acta Cytol. 2003 Nov-Dec;47(6):1131-4.

3. Siddaraju N, Badhe BAhe BA, Fonrepanavar M, Mishra MM. Preoperative fine needle aspiration cytology diagnosis of spindle cell myoepithelioma of the a parotid gland: a case report. Acta Cytol. 2008 May-Jul; 53(4):495-9.

4. Kajor M, Gierek T, Markowski J, Pajak J. Schwannomalike mixed tumor of the parotid gland: a case report. Acta Cytol. 2006 Sep-Oct; 50(5):529-30. 